Article

OSIPE, J.B. ${ }^{*}$

OLIVEIRA JR., R.S. ${ }^{2}$

CONSTANTIN, J. ${ }^{2}$

TAKANO, H.K. ${ }^{2}$

BIFFE, D.F. ${ }^{2}$

\section{SPECTRUM OF WeEd CONTROL WiTh 2,4-D AND Dicamba HeRbicides Associated TO GLYPHOSATE OR NOT}

\author{
Espectro de Controle de Plantas Daninhas com os Herbicidas 2,4-D e Dicamba \\ Associados ou Não ao Glyphosate
}

\begin{abstract}
The possibility of using auxin mimics herbicides in culture postemergence applications contributes to weed management. This study aimed at evaluating and comparing the effectiveness of 2,4-D and dicamba herbicides on glyphosate resistant or tolerant weeds. The treatments were dicamba and 2,4-D doses with or without glyphosate. The evaluated weeds in the experiment were Richardia brasiliensis, Commelina benghalensis, Conyza sp. and Ipomoea nil. Herbicides were applied when weeds were in 4 to 6 and 10 to 12 leaves stages. Data referring to evaluations on day 30 after application were submitted to analysis of variance. Response-dose curves were obtained for herbicides, and $\mathrm{C}_{85}$ and $\mathrm{C}_{95}$ values were identified. Weed species showed different tolerance to dicamba and 2,4-D, and differences were more evident for $C$. benghalensis. The addition of glyphosate to the auxin mimic reduced the differences between them. For plants in less developed stages, regardless of the species, mixtures of glyphosate $+2,4-\mathrm{D}$ or glyphosate + dicamba provided excellent levels of control. In general, considering equivalent doses, for $R$. brasiliensis, C. benghalensis and I. nil, 2,4-D herbicide was superior to dicamba. As for Conyza bonariensis, dicamba showed better control percentages.
\end{abstract}

Keywords: mimics auxin, weeds, Richardia brasiliensis, Commelina benghalensis, Conyza bonariensis, Ipomoea nil.

RESUMO - A possibilidade de utilização de herbicidas mimetizadores de auxina em
aplicações de pós-emergência das culturas pode contribuir para o manejo da
comunidade infestante. O presente trabalho teve por objetivos avaliar e comparar a
eficiência dos herbicidas $2,4-D$ e dicamba sobre plantas daninhas resistentes ou
tolerantes ao glyphosate. Os tratamentos utilizados foram doses de dicamba e 2,4-D
associados ou não ao glyphosate. As espécies avaliadas foram Richardia brasiliensis,
Commelina benghalensis, Conyza sp. e Ipomoea nil. Os herbicidas foram aplicados
quando as plantas daninhas estavam com 4 a 6 folhas e 10 a 12 folhas. Os dados
referentes às avaliações de controle aos 30 dias após a aplicação foram submetidos
à análise de variancia. Foram obtidas curvas de dose-resposta para os herbicidas e
identificadas as doses para $80 \%$ e $95 \%\left(C_{80}\right.$ e $C_{95}$ ) de controle. As espécies avaliadas
apresentaram suscetibilidade diferenciada ao dicamba e 2,4-D, sendo as diferenças
mais evidentes para as plantas de C. benghalensis. A adição do glyphosate aos
mimetizadores de auxina reduziu as diferenças de eficiência entre esses mimetizadores.
Para plantas em estádios menos desenvolvidos, independentemente da espécie, as
misturas de glyphosate+2,4-D ou glyphosate+dicamba proporcionaram excelentes
niveis de controle. De maneira geral, considerando doses equivalentes, para as
plantas de $\boldsymbol{R}$. brasiliensis, I. nil e C. benghalensis, o herbicida 2,4-D mostrou-se
superior ao dicamba. Já para Conyza bonariensis, o dicamba apresentou maiores
porcentagens de controle.

Palavras-chave: mimetizadores de auxina, plantas daninhas, Richardia brasiliensis, Commelina benghalensis, Conyza bonariensis, Ipomoea nil.

1 Universidade Estadual do Norte do Paraná, Bandeirantes-PR, Brasil; ${ }^{2}$ Universidade Estadual de Maringá, Maringá-PR, Brasil. 


\section{INTRODUCTION}

In response to the increased incidence of weeds that are resistant to glyphosate and other herbicides, seed companies have developed hybrids and varieties with resistance to more than one herbicide (Vink et al., 2012). There is the possibility of launching cultures that present resistance to dicamba and 2,4-D herbicides, as well as glyphosate.

These herbicides, classified as auxin mimics, have been used for more than 70 years (Goggin et al., 2016), and in Brazil, resistance cases were reported only from two species (Heap, 2016). Therefore, herbicides from this group are extremely important tools to control weeds that are resistant and tolerant to different action mechanisms of auxin mimics (Preston et al., 2009).

Auxinic herbicides normally control a great number of dicotyledonous weed species, including some key-species that developed resistance to glyphosate (Green and Owen 2010). For Amaranthus palmeri, an extremely relevant plant in the North American territory, the addition of dicamba to glyphosate considerably elevates control levels (Spaunhorst and Bradley, 2013). A similar situation occurs for fleabane plants (Conyza spp.), which are more easily controlled when glyphosate is associated to 2,4-D or dicamba (Owen et al., 2011; Soares et al., 2012). Vink et al. (2012), in experiments with glyphosate-resistant Ambrosia trifida, verified that dicamba is an excellent option to control the species.

As well as glyphosate-resistant species, plants that are tolerant to this herbicide are another problem coming from the constant use of RR technology. In Brazil, among glyphosate-tolerant species, it is possible to highlight broadleaf buttonweed (Spermacoce latifolia), Benghal dayflower (Commelina benghalensis), coatbuttons (Tridax procumbens), tropical Mexican clover (Richardia brasiliensis) and morning glory (Ipomoea grandifolia) (Procópio et al., 2007; Takano et al., 2013). For these species, the addition of an auxin mimic like 2,4-D to glyphosate accelerates and improves control levels (Takano et al., 2013). Even with the use of dicamba in maize and wheat cultures during previous decades (Behrens et al., 2007; Cao et al., 2011), there is little information related to the herbicide effectiveness on these weed species. Currently, no dicamba-based commercial product is registered to be used in Brazil.

Considering this, the goals of this experiment were to evaluate and compare the effectiveness of 2,4-D and dicamba herbicides in controlling weeds on which glyphosate presents low effectiveness, due to resistance or tolerance.

\section{MATERIAL AND METHODS}

Experiments were conducted in a greenhouse between January 2014 and April 2015, in the Irrigation Training Center of the Universidade Estadual de Maringá (UEM), in the city of Maringá, Paraná state.

The soil that was used in the experiments was sieved and placed in plastic planters with $4 \mathrm{dm}^{3}$ capacity. Each planter was considered as an experimental unit. Physical-chemical soil characteristics were: 5.3 water $\mathrm{pH} ; 3.3 \mathrm{cmol}_{\mathrm{c}} \mathrm{H}^{+}+\mathrm{Al}^{+3} \mathrm{dm}^{-3}$ soil; $0,9 \mathrm{cmol}_{\mathrm{c}} \mathrm{dm}^{-3} \mathrm{Ca}^{+2}$; $0,4 \mathrm{cmol}_{\mathrm{c}} \mathrm{dm}^{-3} \mathrm{Mg}^{+2} ; 0,29 \mathrm{cmol}_{\mathrm{c}} \mathrm{dm}^{-3} \mathrm{~K}^{+} ; 17,0 \mathrm{mg} \mathrm{dm}^{-3} \mathrm{P}$ (Mehlich); 17,2 $\mathrm{g} \mathrm{dm}^{-3}$ organic matter; 56,8\% coarse sand; $17,1 \%$ fine sand; $5,6 \%$ silt; and $20,5 \%$ clay.

The adopted experimental design was completely randomized, arranged in a $11 \times 2$ factor scheme with four replications (11 were control samples), with and without the addition of glyphosate herbicide (960 g a.e. $\mathrm{ha}^{-1}$ ). The 11 control samples were 201.6, 403.2, 694.8, 806.4 and 1,008 g a.e. ha ${ }^{-1}$ dicamba, 201.6, 403.2, 694.8, 806.4 and 1,008 g a.e. ha-1 2,4-D and one control sample with no auxin mimic application.

Weed species evaluated in the experiment were: Richardia brasiliensis (white-eye), Commelina benghalensis (Benghal dayflower), Conyza bonariensis (fleabane) and Ipomoea nil (morning glory). Applications were performed during two stages (4-6 leaves and 10-12 leaves), so that each stage of each plant was considered an isolated experiment, totalizing eight experiments.

After seeding of the mentioned species, planters were irrigated twice a day with $3 \mathrm{~mm}$ blades. After their emergence, thinning was performed, leaving four plants per pot, in the lower stage, 
and one or two plants in the higher stage. When plants reached the mentioned stages, planters were removed from the greenhouse and herbicides were applied. Applications in the different experiments did not occur on the same day, due to the distinct growth speeds of the species.

For the application, a $\mathrm{CO}_{2}$-based constant pressure backpack sprayer was used, equipped with a bar with three XR-110.02 fan type nozzles, spaced $50 \mathrm{~cm}$ apart, under pressure of $2.0 \mathrm{kgf} \mathrm{cm}^{-2}$. These application conditions provided a $200 \mathrm{~L} \mathrm{ha}^{-1}$ application rate. During application, climate conditions were: temperature between 22 and $27{ }^{\circ} \mathrm{C}, 85 \%$ air relative humidity and winds from 2.7 to $3.6 \mathrm{~km} \mathrm{~h}^{-1}$.

Control evaluations were performed on day 30 after herbicide application (DAA), through a $0-100 \%$ visual scale, where 0\% represents null herbicide effect in plants, and $100 \%$ represents their death.

Evaluation data were submitted to analysis of variance (F test at $5 \%$ ), and response-dose curves were obtained for dicamba and 2,4-D herbicides, associated to glyphosate or not. For all figures, standard deviation values from each treatment were demonstrated in the form of bars. The used non-linear regression model is described hereinafter (Streibig, 1988):

$$
y=\frac{a}{\left[1+\left(\frac{x}{X_{0}}\right)^{b}\right]}
$$

where: $y=$ percentage control; $\mathrm{x}=$ herbicide dose (g a.e. ha ${ }^{-1}$ ); $a, X_{0}$ and $b=$ estimated equation coefficients, so that: $\mathrm{a}=$ function maximum asymptote; $X_{O}=$ dose that provides $50 \%$ control of the function maximum asymptote value; and $b=$ curve gradient around $\mathrm{X}_{0}$.

Starting from these equations, response-dose curves were elaborated. Based on the adjusted models, the calculation of herbicide doses that provided $80 \%$ and $95 \%$ control $\left(\mathrm{C}_{80}\right.$ and $\left.\mathrm{C}_{95}\right)$ was performed, with the help of the Sigma Plot 11.0 software.

\section{RESULTS AND DISCUSSION}

The adjusted models for Richardia brasiliensis plants with 4-6 leaves (Figure 1A) reveal that, initially, function growth rates were elevated; this indicates high control levels for the species, even with lower doses. Increased herbicide doses promoted higher control percentages, which reached $100 \%$ effectiveness in both products. Nevertheless, 2,4-D herbicide controlled whiteeye plants more easily, which can be seen by the obtained $\mathrm{C}_{95}$ values (Table 1). As for dicamba, the necessary dose to control $95 \%$ was 471.2 g a.e. ha ${ }^{-1}$, whereas for $2,4-\mathrm{D}$ the dose was $246.1 \mathrm{~g}$ a.e. $\mathrm{ha}^{-1}$. With the addition of glyphosate to dicamba and 2,4-D herbicides (Figure 1B), there was total control of the species, not being possible to adjust the model. All treatments exceeded $100 \%$ control, even glyphosate when applied individually.

As for white-eye plants in the 10-12 leaves stage (Figure 2A), it is possible to observe that the differences between auxin mimics remained. For similar doses of the two auxin mimics, 2,4-D showed higher control than dicamba; this continued until the $700 \mathrm{~g}$ a.e. ha $^{-1}$ dose, starting from which both products presented total control over the species $(100 \%)$. In Table $2, \mathrm{C}_{80}$ and $\mathrm{C}_{95}$ herbicide values are presented, and it is possible to observe increasing values for dicamba herbicide. In order to obtain 80\% control, the necessary doses were $212.2(2,4-\mathrm{D})$ and 255.7 (dicamba) g a.e. ha-1 ${ }^{-1}$ These values are lower than the normally used 2,4-D doses (Rodrigues and Almeida, 2011) and, possibly, are also lower than the dicamba dose whose register has been searched in Brazil (close to $480 \mathrm{~g}$ a.e. ha-1).

With the addition of glyphosate to auxin mimics (Figure 2B), control levels grew more rapidly, and all tested doses presented satisfactory control levels. In this case, the individual application of glyphosate performed only $66 \%$ control, which highlights the benefit of adding dicamba or 2,4-D to control white-eye plants in more advanced stages. Moreover, it is possible to observe through $\mathrm{C}_{80}$ values (Table 2) that the addition of glyphosate to auxin mimics allowed reducing doses of approximately $28 \%$, both for dicamba and 2,4-D. Takano et al. (2013) support these results by showing that, in Richardia brasiliensis plants with more than 10 leaves, the individual 
(A) White-eye -4 to 6 leaves (30 DAA)

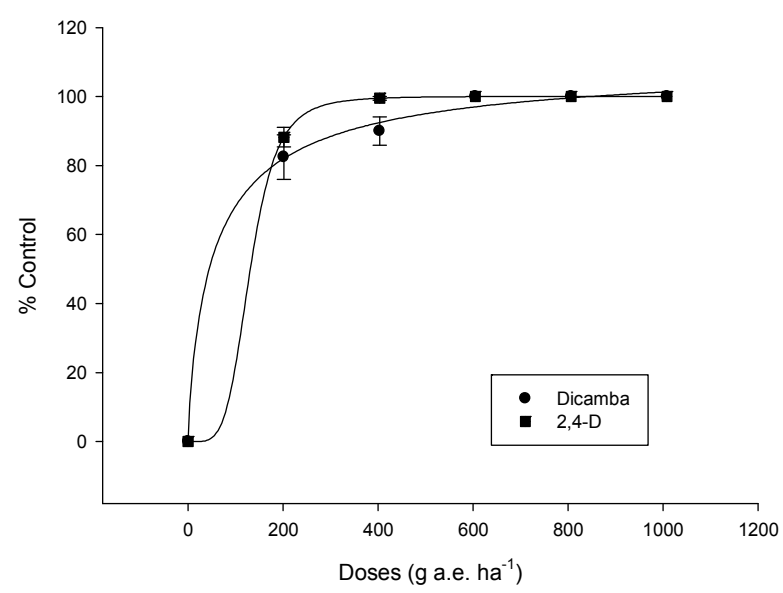

(B)

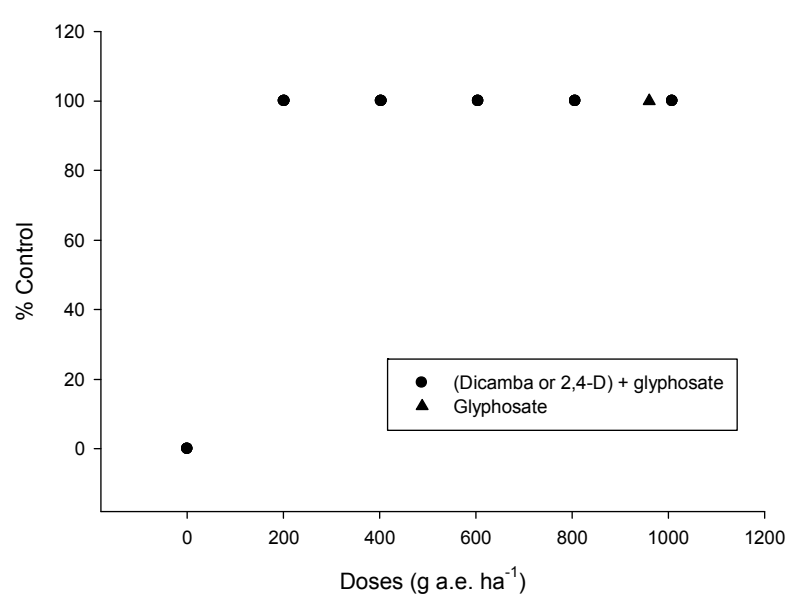

Bars represent the standard deviation of the average in each treatment.

Figure 1 - Response-dose curves for white-eye (Richardia brasiliensis) plants in the 4-6 leaves stage, with isolated dicamba and 2,4-D (A) and in combination with glyphosate at 960 g a.e. ha-1 (B). Maringá - Paraná state, 2012.

Table 1 - Estimates of $\mathrm{a}, \mathrm{b}$ and $\mathrm{X}_{0}$ parameters, determination coefficient $\left(\mathrm{R}^{2}\right)$ of the adjusted model and doses for $80 \%$ and $95 \%$ control of Richardia brasiliensis (4 to 6 leaves), on day 30 DAA. Maringá - Paraná state, 2012

\begin{tabular}{|l|c|c|c|c|c|c|}
\hline \multirow{2}{*}{ Herbicide } & $\mathrm{a}$ & $\mathrm{b}$ & \multirow{2}{*}{$\mathrm{X}_{0}$} & \multirow{2}{*}{$\mathrm{R}^{2}$} & $\mathrm{C}_{95}$ & $\mathrm{C}_{80}$ \\
\cline { 5 - 7 } & & & & & \multicolumn{2}{c|}{$\left(\mathrm{g} \mathrm{a.e.} \mathrm{ha}^{-1}\right)$} \\
\hline Dicamba & 110.79 & -0.82 & 56.26 & 0.99 & 471.2 & 180.1 \\
\hline 2,4-D & 100.03 & -4.67 & 130.85 & 0.99 & 246.1 & 176.2 \\
\hline Dicamba+glyphosate & - & - & - & - & - & - \\
\hline 2,4-D+glyphosate & - & - & - & - & - & - \\
\hline
\end{tabular}

application of 720 g a.e. ha-1 glyphosate did not perform satisfactory control on the species. With the addition of 2,4-D herbicide, control percentages were 100\%. Even if 2,4-D and dicamba herbicides are classified as auxin mimics, they belong to different chemical groups $(2,4 \mathrm{D}$ phenolcarboxylic acids; dicamba - benzoic acids), which may contribute to the susceptibility differences observed among species (Grossmann, 2010).

There are apparently two types of chemical receptors that sense auxin presence in vegetables (Kelley and Riechers, 2007). One of them would be ABP1 (Auxin Binding Protein 1), a protein found in the endoplasmatic reticulum and in the plasma membrane that codifies a signal inducing super activity in the proton pumps in the membrane.

The other and more recently discovered auxin receptor group is F-Box proteins: TIR1 (transport inhibitor response)/AFB (auxin-signaling F-box). These proteins are part of the SCF ubiquitin ligase complex (Skp1-cullin-F-box protein), which performs the ubiquitination of some target proteins, degrading them through ubiquitin proteasome (Dharmasiri et al., 2005; Gleason et al., 2011 ). In the core of plant cells there are ARF's (auxin response factors), genes that are activated only with the presence of auxins. The activation of these genes induces ACC (1Aminocyclopropane-1-carboxylic acid) synthase, which elevates ACC concentration, an ethylene precursor. The effects of increased ethylene concentrations in plants are leaf epinasty, tissue swelling and plant senescence, as well as being the trigger for an increase in the production of abscisic acid (ABA). Increased levels of this hormone promote stomata closing, which limits transpiration and carbon assimilation, and the "super production" of reactive oxygen species (Grossman, 2000, 2010; Christoffoleti et al., 2015). 
(A)

White-eye - 10 to 12 leaves (30 DAA)

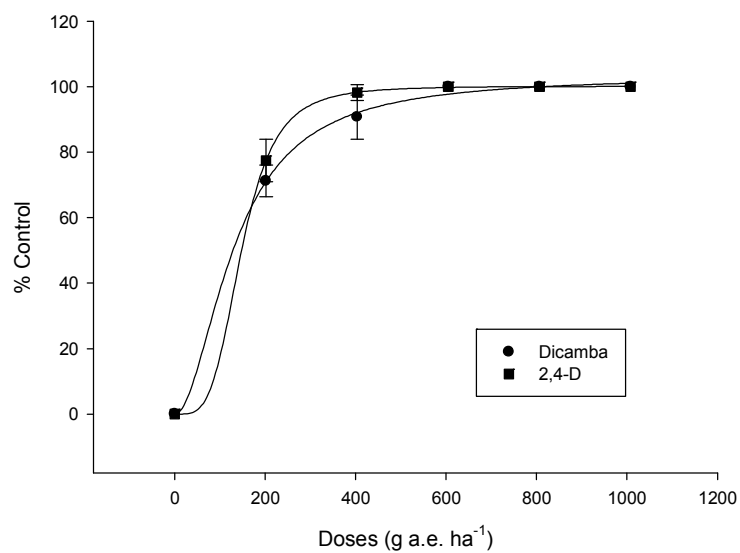

(B)

White-eye - 10 to 12 leaves (30 DAA)

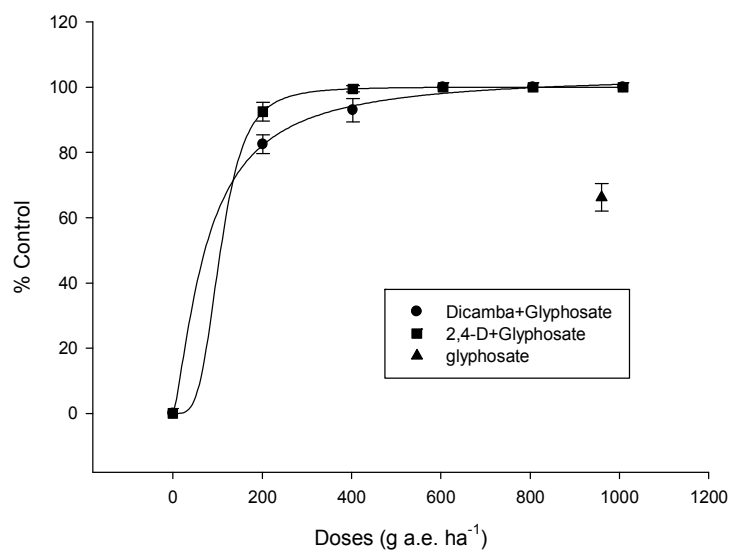

Bars represent the standard deviation of the average in each treatment.

Figure 2 - Response-dose curves for white-eye (Richardia brasiliensis) plants in the 10-12 leaves stage, with isolated dicamba and 2,4-D (A) and in combination with glyphosate at 960 g a.e. ha-1 (B). Maringá - Paraná state, 2012.

Table 2 - Estimates of $\mathrm{a}, \mathrm{b}$ and $\mathrm{X}_{0}$ parameters, determination coefficient $\left(\mathrm{R}^{2}\right)$ of the adjusted model and doses for $80 \%$ and $95 \%$ control of Richardia brasiliensis (10 to 12 leaves), on day 30 DAA. Maringá - Paraná state, 2012

\begin{tabular}{|l|c|c|c|c|c|c|}
\hline \multirow{2}{*}{ Herbicide } & $\mathrm{a}$ & $\mathrm{b}$ & \multirow{2}{*}{$\mathrm{X}_{0}$} & \multirow{2}{*}{$\mathrm{R}^{2}$} & $\mathrm{C}_{95}$ & $\mathrm{C}_{80}$ \\
\cline { 5 - 7 } & & & & & \multicolumn{2}{c|}{$\left(\mathrm{g}\right.$ a.e. $\left.\mathrm{h}^{-1}\right)$} \\
\hline Dicamba & 103.24 & -1.89 & 132.80 & 0.99 & 482.3 & 255.7 \\
\hline 2,4-D & 100.16 & -3.95 & 147.70 & 0.99 & 309.1 & 212.2 \\
\hline Dicamba+glyphosate & 103.80 & -1.37 & 75.52 & 0.99 & 433.0 & 183.5 \\
\hline 2,4-D+glyphosate & 100.05 & -3.93 & 106.61 & 0.99 & 225.3 & 151.9 \\
\hline
\end{tabular}

Even if dicamba and 2,4-D herbicides induce plants to reveal similar responses, Gleason et al. (2011), in studies with Arabidopsis mutants, showed that some of these studied mutants presented different sensitivities to dicamba and 2,4-D. These authors highlight two important points for these differences. One refers to the differentiated cellular absorption of synthetic auxins, which may influence herbicide efficacy. Arabidopsis mutants of AXR4, an important protein in auxin transport, presented differentiated tolerance between 2,4-D and dicamba (Gleason et al., 2011). Thompson Jr et al. (1973) demonstrated that, in order to control Campsis radicans species, dicamba herbicide appeared to be more effective than 2,4-D, and as a justification, the authors stated that herbicide absorption and translocation levels were different, being higher for dicamba.

The other factor of differentiated selectivity to synthetic auxins may be verified according to the different receptor proteins of the F-Box family. Arabidopsis plants containing AFB5 mutations (homologous to TIR1 proteins) presented specific resistance to dicamba herbicide but not to 2,4-D. Thus, it is possible that other members of the TIR1/AFB family have differentiated specificity to auxin mimics of different chemical groups, which may influence the signalization of herbicide molecules inside plants (Gleason et al., 2011).

In the adjusted model for 4-6 leaves Benghal dayflower (Commelina benghalensis) control, for dicamba herbicide (Figure 3A), within the tested doses range, the curve did not reach maximum asymptote (103.76). The analysis of isolated herbicides (Figure 3A) reveals that 2,4-D was more effective than dicamba in controlling Benghal dayflower. All 2,4-D doses provided 100\% control for the species, whereas dicamba did not reach this control level. However, with glyphosate addition (Figure 3B), differences between auxin mimics were minimum and, starting from a $226.1 \mathrm{~g}$ a.e. ha ${ }^{-1}$ dicamba dose, control percentages were higher than $95 \%$ (Table 3). Individually applied glyphosate provided almost $75 \%$ control. In order to control this species, the addition of a 
(A) Benghal dayflower - 4 to 6 leaves (30 DAA)

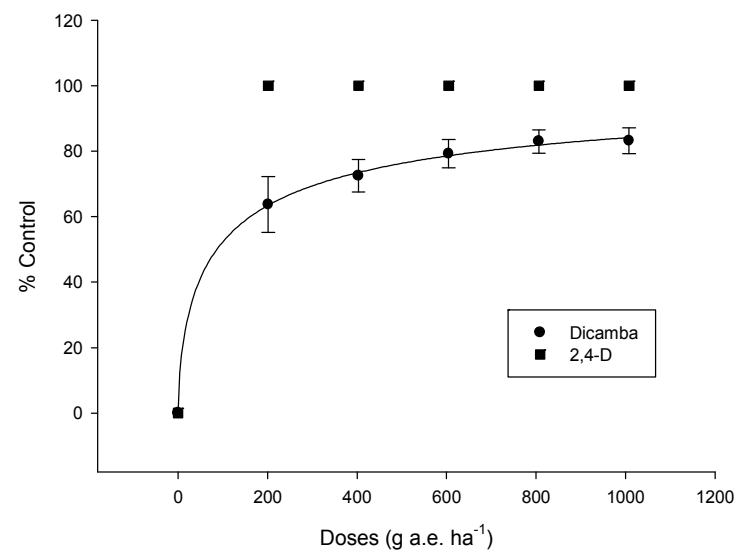

(B) Benghal dayflower -4 to 6 leaves (30 DAA)

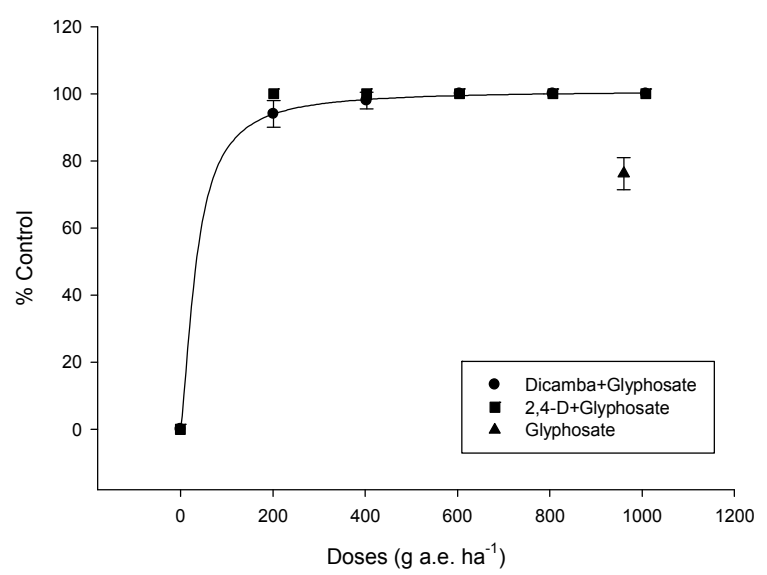

Bars represent the standard deviation of the average in each treatment.

Figure 3 - Response-dose curves for Benghal dayflower (Commelina benghalensis) plants in the 4-6 leaves stage, with isolated dicamba and 2,4-D (A) and in combination with glyphosate at 960 g a.e. ha-1 (B). Maringá - Paraná state, 2012.

Table 3 - Estimates of $\mathrm{a}, \mathrm{b}$ and $\mathrm{X}_{0}$ parameters, determination coefficient $\left(\mathrm{R}^{2}\right)$ of the adjusted model and doses for $80 \%$ and $95 \%$ control of Commelina benghalensis (4 to 6 leaves), on day 30 DAA. Maringá - Paraná state, 2012

\begin{tabular}{|l|c|c|c|c|c|c|}
\hline \multirow{2}{*}{ Herbicide } & \multirow{2}{*}{$\mathrm{a}$} & $\mathrm{b}$ & \multirow{2}{*}{$\mathrm{X}_{0}$} & \multirow{2}{*}{$\mathrm{R}^{2}$} & $\mathrm{C}_{95}$ & $\mathrm{C}_{80}$ \\
\cline { 5 - 7 } & & & & & \multicolumn{2}{c|}{$\left(\mathrm{g}_{\left.\mathrm{g} . \mathrm{e} . \mathrm{ha}^{-1}\right)}\right.$} \\
\hline Dicamba & 103.57 & -0.63 & 96.68 & 0.98 & $>1008.0$ & 681.1 \\
\hline 2,4-D & - & - & - & - & - & - \\
\hline Dicamba+glyphosate & 100.94 & -1.47 & 34.57 & 0.99 & 226.1 & 84.2 \\
\hline 2,4-D+glyphosate & - & - & - & - & - & - \\
\hline
\end{tabular}

second herbicide has proved necessary (Monquero et al., 2001; Norsworthy and Grey, 2004; Maciel et al., 2011), and auxin mimic herbicides are feasible options.

As well as for the previous stage, for Benghal dayflower plants with 10-12 leaves (Figure 4A), 2,4-D herbicide was superior to dicamba in controlling the species. $\mathrm{C}_{95}$ value for isolated 2,4-D was $608.1 \mathrm{~g}$ a.e. ha ${ }^{-1}$, whereas isolated dicamba did not reach this control level in the studied dose range (Table 4). Most herbicides, except for 2,4-D, are ineffective in controlling Benghal dayflower in the adult stage with a single application (Ronchi et al., 2001). Individually applied dicamba performed 60\% maximum control. In treatments with glyphosate (Figure 4B), the adjusted models presented higher initial growth rate. As for 2,4-D, control levels quickly reached 100\%, which may be proved by the small $\mathrm{C}_{95}$ value that was found (164.2 g a.e. ha-1 - Table 4). As for dicamba, control did not reach $95 \%$ within the tested dose range. In spite of this, it was possible to obtain satisfactory control $(80 \%)$ with the $483.3 \mathrm{~g}$ a.e. ha- ${ }^{-1}$ dose.

Thus, aiming at the control of Benghal dayflower plants in lower stages, a situation that is more common inside cultures, the addition of glyphosate to dicamba or 2,4-D is enough to perform control. In case of bigger plants, such as in management applications, 2,4-D would be more appropriate than dicamba.

Response-dose curves for the control of morning glory (I. nil) in 4-6 leaves stage are in Figure 5, and estimates of adjusted model parameters with $\mathrm{C}_{95}$ and $\mathrm{C}_{80}$ values, in Table 5 . Curves obtained for isolated dicamba and 2,4-D herbicides practically overlap, indicating that the differences between them in controlling plants from this species between 4 and 6 leaves are minimum. This may be confirmed by very similar values of $\mathrm{C}_{95}\left(292.9\right.$ and $268.7 \mathrm{~g}$ a.e. ha ${ }^{-1}$ for dicamba and 2,4-D, respectively) and $\mathrm{C}_{80}$ (208.2 and $192.7 \mathrm{~g}$ a.e. ha ${ }^{-1}$ for dicamba and 2,4-D, respectively). 
(A) Benghal dayflower - 10 to 12 leaves (30 DAA)

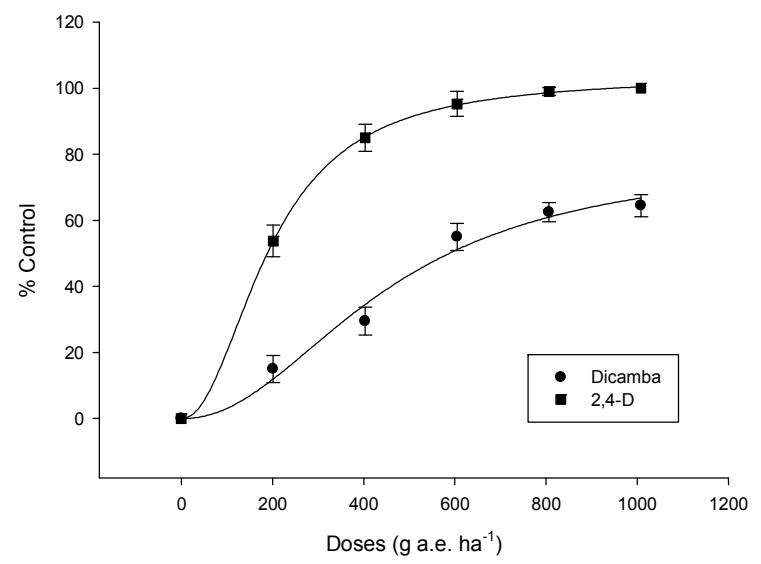

(B) Benghal dayflower - 10 to 12 leaves (30 DAA)

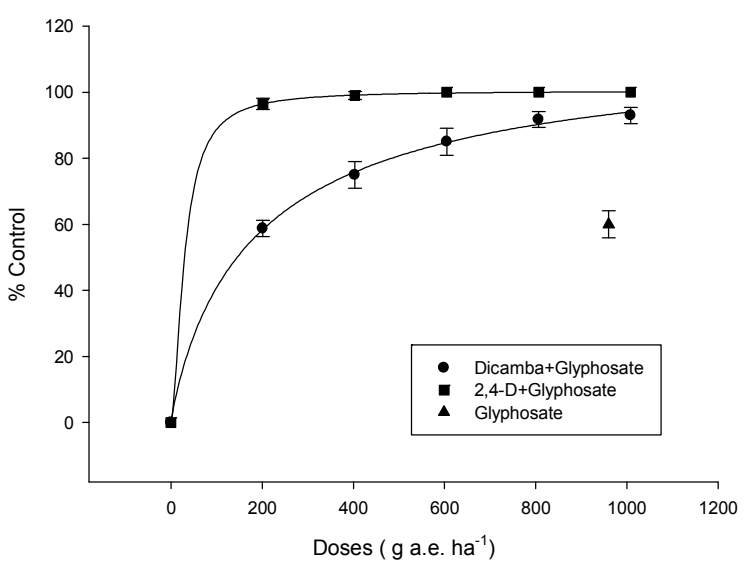

Bars represent the standard deviation of the average in each treatment.

Figure 4 - Response-dose curves for Benghal dayflower (Commelina benghalensis) plants in the 10-12 leaves stage, with isolated dicamba and 2,4-D (A) and in combination with glyphosate at $960 \mathrm{~g}$ a.e. ha ${ }^{-1}$ (B). Maringá - Paraná state, 2012.

Table 4 - Estimates of a, $\mathrm{b}$ and $\mathrm{X}_{0}$ parameters, determination coefficient $\left(\mathrm{R}^{2}\right)$ of the adjusted model and doses for $80 \%$ and $95 \%$ control of Commelina benghalensis (10 to 12 leaves), on day 30 DAA. Maringá - Paraná state, 2012

\begin{tabular}{|l|r|r|r|r|r|r|}
\hline \multirow{2}{*}{ Herbicide } & \multirow{2}{*}{$\mathrm{a}$} & $\mathrm{b}$ & \multirow{2}{*}{$\mathrm{X}_{0}$} & \multirow{2}{*}{$\mathrm{R}^{2}$} & \multicolumn{1}{c|}{$\mathrm{C}_{95}$} & \multicolumn{2}{c|}{$\mathrm{C}_{80}$} \\
\cline { 5 - 7 } & & & & & \multicolumn{2}{|c|}{$\left(\mathrm{g}_{\text {a.e. }} \mathrm{h}^{-1}\right)$} \\
\hline Dicamba & 79.25 & -2.11 & 455.74 & 0.96 & $>1008.0$ & $>1008.0$ \\
\hline 2,4-D & 103.52 & -2.11 & 194.60 & 0.99 & 608.3 & 349.4 \\
\hline Dicamba+glyphosate & 116.05 & -0.89 & 197.91 & 0.99 & $>1008.0$ & 483.3 \\
\hline 2,4-D+glyphosate & 100.39 & -1.68 & 29.81 & 0.99 & 164.2 & 68.9 \\
\hline
\end{tabular}

Glyphosate addition to auxin mimics provided $100 \%$ control for all tested doses. The treatment with individual glyphosate application performed total control of the species, and therefore the adjustment of mathematical models was not possible, nor was it obtaining $\mathrm{C}_{95}$ and $\mathrm{C}_{80}$ values.

The response of morning glory plants with 10-12 leaves to treatments may be analyzed in Figure 6 and Table 7. It is possible to observe that 2,4-D applications promoted high control levels of morning glory plants with 10-12 leaves, even with the lowest tested dose, which did not occur for dicamba herbicide. The curve for 2,4-D herbicide reached the asymptote $(100 \%)$ with the use of doses close to $400 \mathrm{~g}$ a.e. ha ${ }^{-1}$, whereas dicamba did not reach $100 \%$ effectiveness with the tested dose range. The necessary dose of isolated dicamba to reach $95 \%$ control $\left(\mathrm{C}_{95}\right)$ was 2.5 times higher than the one of isolated 2,4-D (Table 6). However, glyphosate herbicide addition to dicamba or 2,4-D resulted in the absence of differences between auxin mimics, because control levels reached 100\% (Figure 8B). The individual application of glyphosate performed $83.8 \%$ control.

Thus, it is possible to state that, for $I$. nil plants in the 4 to 6 leaves stage, individual applications of dicamba or 2,4-D were enough to control the species. For bigger plants (10 to 12 leaves), differences between dicamba and 2,4-D were more evident; in individual applications, the latter was superior to the former. However, with the addition of glyphosate to auxin mimics herbicides, control levels reached 100\%.

Response-dose curves for fleabane plants with 4-6 leaves, and estimates of adjusted model parameters, determination coefficients $\left(\mathrm{R}^{2}\right)$ and $\mathrm{C}_{95}$ and $\mathrm{C}_{80}$ values are in Figure 7 and Table 7 . For individually applied herbicides (Figure 7A), it is observed that, in the lowest doses, dicamba preformed higher fleabane control than 2,4-D. $\mathrm{C}_{95}$ values were 362.2 and $534.9 \mathrm{~g}$ a.e. ha ${ }^{-1}$ for dicamba and 2,4-D, respectively. However, in higher than $600 \mathrm{~g}$ a.e. ha ${ }^{-1}$ doses, control levels were close to $100 \%$ for both herbicides. 
(A) Morning glory - 4 to 6 leaves (30 DAA)

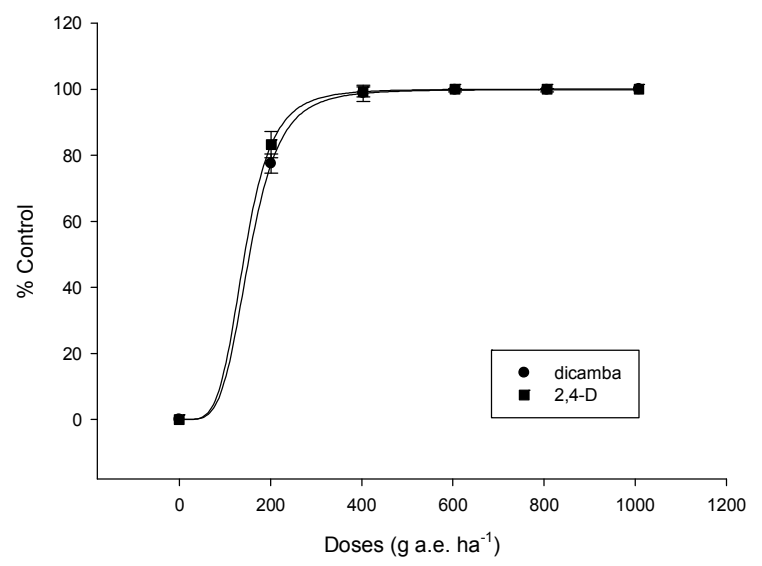

(B) Morning glory - 4 to 6 leaves (30 DAA)

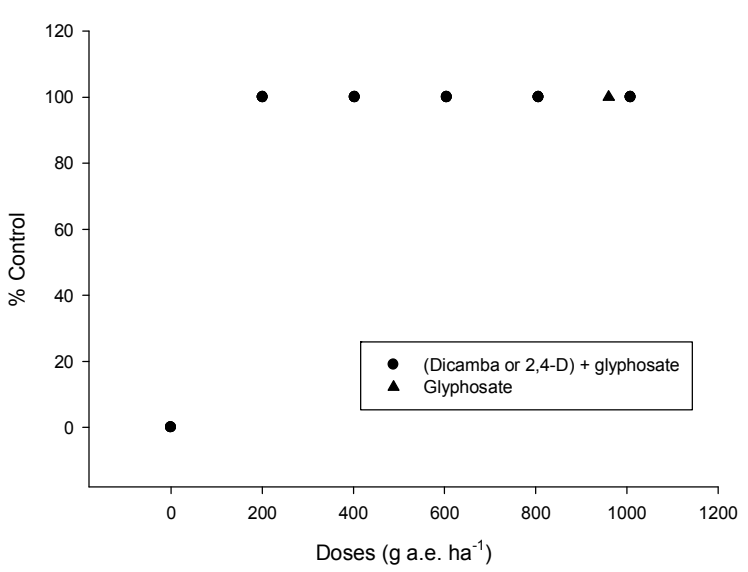

Bars represent the standard deviation of the average in each treatment.

Figure 5 - Response-dose curves for morning glory (Ipomoea nil) plants in the 4-6 leaves stage, with isolated dicamba and 2,4-D (A) and in combination with glyphosate at $960 \mathrm{~g}$ a.e. ha-1 (B). Maringá - Paraná state, 2012.

Table 5 - Estimates of $\mathrm{a}, \mathrm{b}$ and $\mathrm{X}_{0}$ parameters, determination coefficient $\left(\mathrm{R}^{2}\right)$ of the adjusted model and doses for $80 \%$ and $95 \%$ control of Ipomoea nil (4 to 6 leaves), on day 30 DAA. Maringá - Paraná state, 2012

\begin{tabular}{|l|c|c|c|c|c|c|}
\hline \multirow{2}{*}{ Herbicide } & \multirow{2}{*}{$\mathrm{a}$} & $\mathrm{b}$ & \multirow{2}{*}{$\mathrm{X}_{0}$} & \multirow{2}{*}{$\mathrm{R}^{2}$} & $\mathrm{C}_{95}$ & $\mathrm{C}_{80}$ \\
\cline { 5 - 8 } & & & & & \multicolumn{2}{c|}{$\left(\mathrm{g} \mathrm{a.e.} \mathrm{ha}^{-1}\right)$} \\
\hline Dicamba & 99.92 & -4.61 & 154.04 & 0.99 & 292.9 & 208.2 \\
\hline 2,4-D & 100.05 & -4.67 & 143.14 & 0.99 & 268.7 & 192.7 \\
\hline Dicamba+glyphosate & - & - & - & - & - & - \\
\hline 2,4-D+glyphosate & - & - & - & - & - & - \\
\hline
\end{tabular}

(A) Morning glory - 10 to 12 leaves (30 DAA)

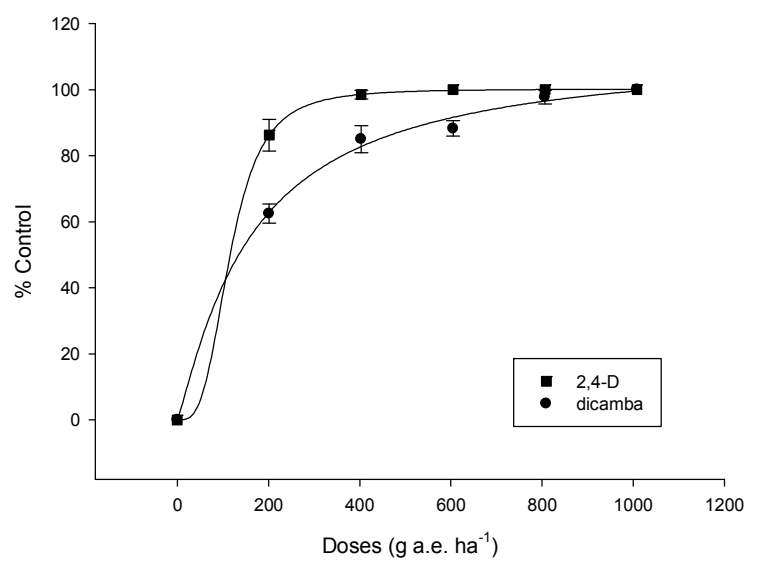

(B) Morning glory - 10 to 12 leaves (30 DAA)

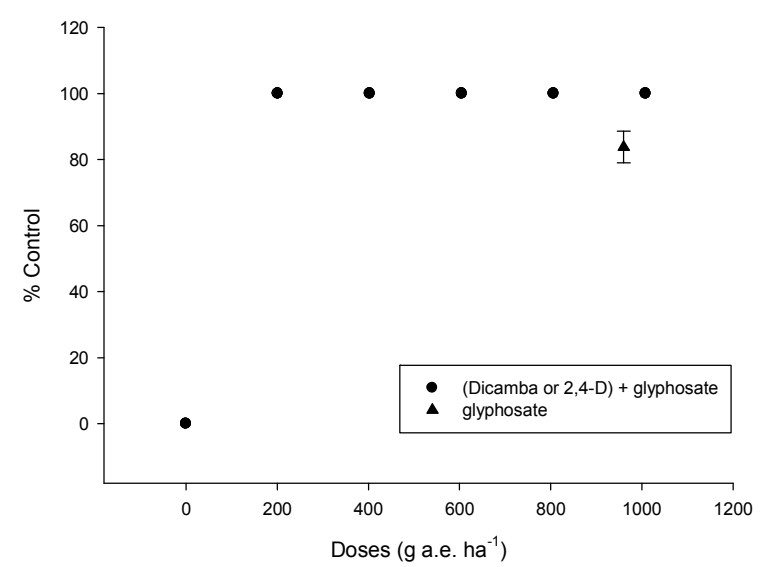

Bars represent the standard deviation of the average in each treatment.

Figure 6 - Response-dose curves for morning glory (Ipomoea nil) plants in the 10-12 leaves stage, with isolated dicamba and 2,4-D (A) and in combination with glyphosate at 960 g a.e. ha-1 (B). Maringá - Paraná state, 2012.

Dicamba 300 and $350 \mathrm{~g}$ a.e. ha $^{-1}$ doses are enough to control fleabane (Conyza canadensis) and, among auxinic herbicides, the one promoting higher fleabane control levels is diglycolamine salt-based dicamba, followed by dimethylamine salt, 2,4-D ester and 2,4-D amine, respectively 
Table 6 - Estimates of $\mathrm{a}, \mathrm{b}$ and $\mathrm{X}_{0}$ parameters, determination coefficient $\left(\mathrm{R}^{2}\right)$ of the adjusted model and doses for $80 \%$ and $95 \%$ control of Ipomoea nil (10 to 12 leaves), on day 30 DAA. Maringá - Paraná state, 2012

\begin{tabular}{|l|c|c|c|c|c|c|}
\hline \multirow{2}{*}{ Herbicide } & \multirow{2}{*}{$\mathrm{a}$} & $\mathrm{b}$ & \multirow{2}{*}{$\mathrm{X}_{0}$} & \multirow{2}{*}{$\mathrm{R}^{2}$} & $\mathrm{C}_{95}$ & \multicolumn{2}{c|}{$\mathrm{C}_{80}$} \\
\cline { 5 - 7 } & & & & & \multicolumn{2}{|c|}{$\left(\mathrm{g} \mathrm{a.e.} \mathrm{ha}^{-1}\right)$} \\
\hline Dicamba & 111.86 & -1.14 & 161.93 & 0.98 & 731.3 & 361.8 \\
\hline 2,4-D & 100.20 & -3.29 & 115.98 & 0.99 & 281.5 & 175.7 \\
\hline Dicamba+glyphosate & - & - & - & - & - & - \\
\hline 2,4-D+glyphosate & - & - & - & - & - & - \\
\hline
\end{tabular}

(A)

Fleabane - 4 to 6 leaves (30 DAA)

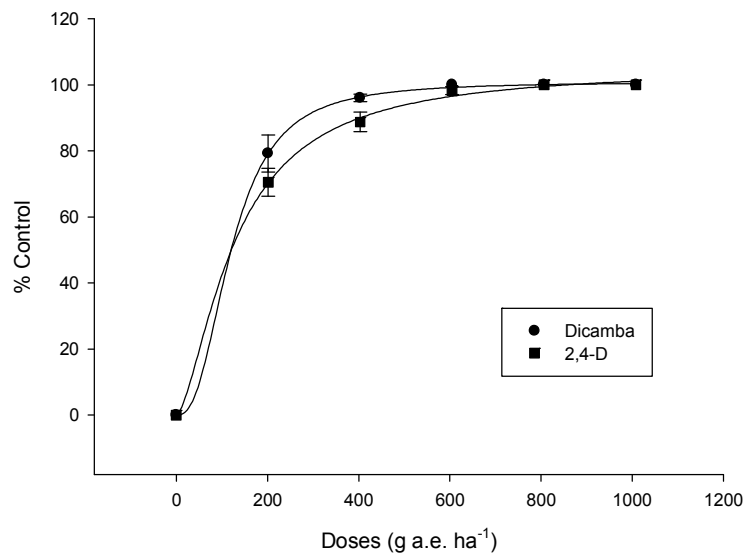

(B)

Fleabane - 4 to 6 leaves (30 DAA)

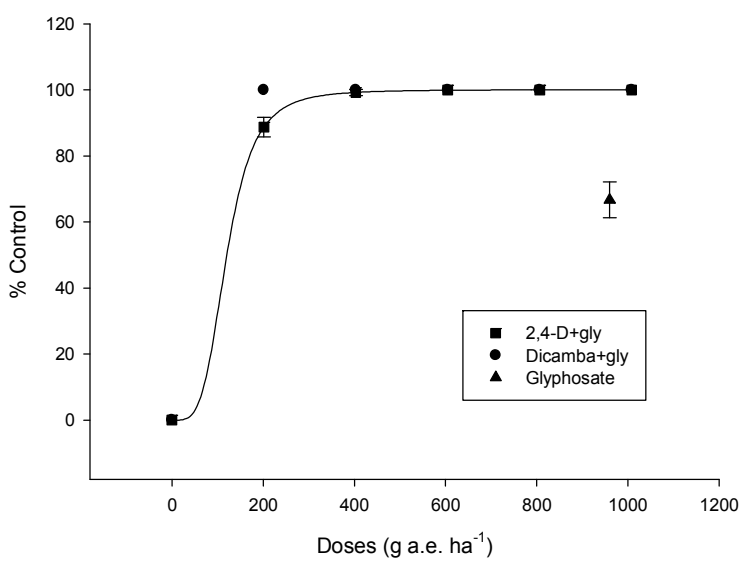

Bars represent the standard deviation of the average in each treatment.

Figure 7 - Response-dose curves for fleabane (Conyza spp.) plants in the 4-6 leaves stage, with isolated dicamba and 2,4-D (A) and in combination with glyphosate at 960 g a.e. ha-1 (B). Maringá - Paraná state, 2012.

Table 7 - Estimates of a, $\mathrm{b}$ and $\mathrm{X}_{0}$ parameters, determination coefficient $\left(\mathrm{R}^{2}\right)$ of the adjusted model and doses for $80 \%$ and $95 \%$ control of Conyza spp. (4 to 6 leaves) on day 30 DAA. Maringá - Paraná state, 2012

\begin{tabular}{|l|c|c|c|c|c|c|}
\hline \multirow{2}{*}{ Herbicide } & \multirow{2}{*}{$\mathrm{a}$} & $\mathrm{b}$ & \multirow{2}{*}{$\mathrm{X}_{0}$} & \multirow{2}{*}{$\mathrm{R}^{2}$} & $\mathrm{C}_{95}$ & \multicolumn{2}{c|}{$\mathrm{C}_{80}$} \\
\cline { 6 - 7 } & & & $\mathrm{g}$ a.e. $\left.\mathrm{ha}^{-1}\right)$ \\
\hline Dicamba & 100.86 & -2.55 & 121.07 & 0.99 & 362.2 & 206.9 \\
\hline 2,4-D & 105.22 & -1.55 & 128.64 & 0.99 & 539.4 & 270.7 \\
\hline Dicamba+glyphosate & - & - & - & - & - & - \\
\hline 2,4-D+glyphosate & 100.07 & -3.99 & 120.35 & 0.99 & 251.1 & 170.7 \\
\hline
\end{tabular}

(Kruger et al., 2010). Fleabane responds in a different way to 2,4-D and dicamba, and dose determination for each herbicide is fundamental (Soares et al., 2012). The authors also state that, even in resistant plants, glyphosate addition may cause additive or synergic effect on control.

In this experiment, even if fleabane plant seeds have been collected in resistance-suspected areas, control performed by glyphosate reached 65\% (Figure 7B). The association of different dicamba and 2,4-D levels to glyphosate resulted in excellent fleabane control levels, except for the $200 \mathrm{~g}$ a.e. $\mathrm{ha}^{-1}$ 2,4-D dose.

As well as for a lower development stage, for 10-12 leaves plants $(20-25 \mathrm{~cm})$, dicamba appeared to be superior to 2,4-D in the lowest tested doses (Figure 8). However, when considering the $670 \mathrm{~g}$ a.e. ha ${ }^{-1}$ 2,4-D dose, which is normally used in association with glyphosate, control levels 
(A)

Fleabane - 10 to 12 leaves (30 DAA)

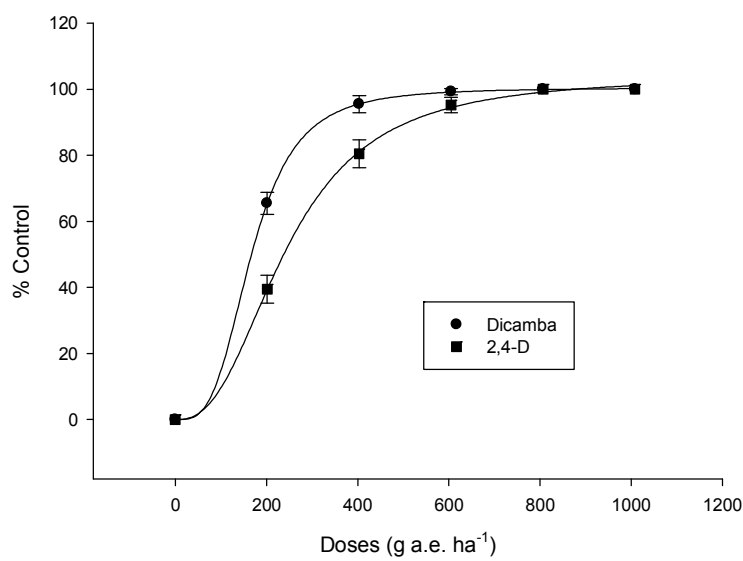

(B) Fleabane - 10 to 12 leaves (30 DAA)

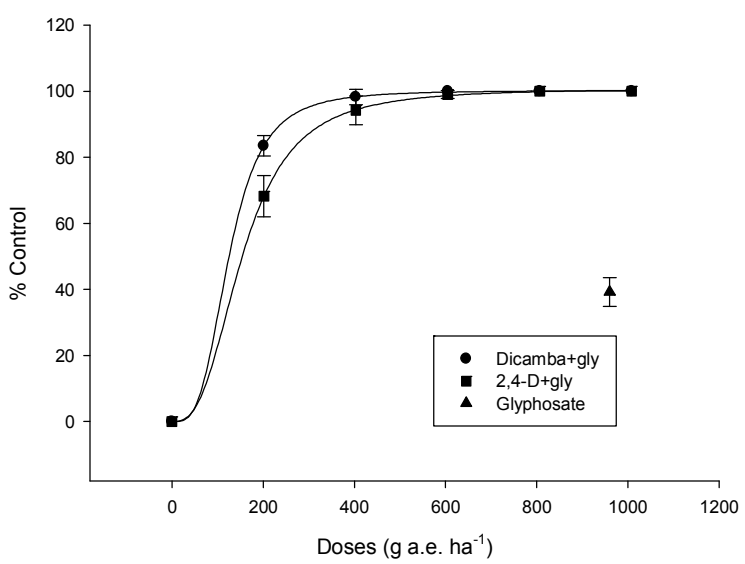

Bars represent the standard deviation of the average in each treatment.

Figure 8 - Response-dose curves for fleabane (Conyza spp) plants in the 10-12 leaves stage, with isolated dicamba and 2,4-D (A) and in combination with glyphosate at 960 g a.e. ha-1 (B). Maringá - Paraná state, 2012.

Table 8 - Estimates of $\mathrm{a}, \mathrm{b}$ and $\mathrm{X}_{0}$ parameters, determination coefficient $\left(\mathrm{R}^{2}\right)$ of the adjusted model and doses for $80 \%$ and $95 \%$ control of Conyza spp. (10 to 12 leaves) on day 30 DAA. Maringá - Paraná state, 2012

\begin{tabular}{|l|c|c|c|c|c|c|}
\hline \multirow{2}{*}{ Herbicide } & \multirow{2}{*}{$\mathrm{a}$} & $\mathrm{b}$ & \multirow{2}{*}{$\mathrm{X}_{0}$} & \multirow{2}{*}{$\mathrm{R}^{2}$} & $\mathrm{C}_{95}$ & \multicolumn{2}{c|}{$\mathrm{C}_{80}$} \\
\cline { 5 - 7 } & & & & & & \multicolumn{2}{c|}{$\left(\mathrm{g}\right.$ a.e. $\left.\mathrm{h}^{-1}\right)$} \\
\hline Dicamba & 100.39 & -3.39 & 167.48 & 0.99 & 391.7 & 250.2 \\
\hline 2,4-D & 103.86 & -2.55 & 244.75 & 0.99 & 621.1 & 393.1 \\
\hline Dicamba+glyphosate & 100.22 & -3.38 & 125.31 & 0.99 & 296.2 & 188.8 \\
\hline 2,4-D+glyphosate & 100.83 & -2.81 & 155.01 & 0.99 & 419.3 & 250.1 \\
\hline
\end{tabular}

were satisfactory. Individual application of 960 g a.e. ha- ${ }^{-1}$ glyphosate provided only $40 \%$ control for the species. With the addition of auxin mimics, control levels were close to $100 \%$ started from the second tested dose. $\mathrm{C}_{95}$ values of dicamba and 2,4-D application in association with glyphosate were 296.2 g a.e. ha ${ }^{-1}$ and 419.3 g a.e. ha ${ }^{-1}$, respectively, which indicates that the addition of glyphosate to dicamba allows an approximately $25 \%$ reduction in the auxin mimic dose. As for $2,4-\mathrm{D}$, the reduction was close to $33 \%$, which indicates the importance of adding glyphosate herbicide to control the species.

Synergic results for dicotyledonous species by 2,4-D + glyphosate or dicamba + glyphosate mixes are described by various authors (Santos et al., 2002; Byker et al., 2013). As well as improving control levels, the application of glyphosate $+2,4-\mathrm{D}$ mix may accelerate plant death (Takano et al., 2013). Flint and Barrett (1989), while studying the effects of combining glyphosate with 2,4-D or dicamba on Convolvulus arvensis plants, verified that the mixes resulted in increased absorption of auxin mimics, which generated synergism for species control. These authors also relate that the synergism of the mix may have occurred according to higher herbicide accumulation in the root region of the species. Lym (2000) observed absorption rates that were three times higher than 2,4-D when applied with glyphosate, compared to 2,4-D individual applications.

Generally speaking, it was observed that weeds presented differentiated susceptibility to auxin mimics, and that these differences were less evident with the addition of glyphosate. Moreover, 2,4-D or dicamba addition to glyphosate in order to control glyphosate tolerant or resistant plants is necessary mainly when these plants are more developed. 


\section{REFERENCES}

Behrens M.R. et al. Dicamba resistance: enlarging and preserving biotechnology-based weed management strategies. Science. 2007;316:1185-7.

Byker H.P. et al. Control of glyphosate-resistant horseweed (Conyza canadensis) with dicamba applied preplant and postemergence in dicamba-resistant soybean. Weed Tecnhol. 2013;27:492-6.

Cao M. et al. Genetic engineering of maize (Zea mays) for high-level tolerance to treatment with the herbicide dicamba. J Agric Food Chem. 2011;59:5830-4.

Christoffoleti P.J. et al. Auxinic herbicides, mechanisms of action, and weed resistance: A look into recent plant science advances. Sci Agric. 2015;72:356-62.

Dharmasiri N. et al. The F-box protein TIR1 is an auxin receptor. Nature. 2005;435:441-5.

Flint J.L., Barrett M. Effects of glyphosate combinations with 2,4-D or dicamba on field bindweed (Convolvulus arvensis). Weed Sci. $1989 ; 37: 12-8$.

Gleason C. et al. Mutant analysis in Arabidopsis provides insight into the molecular mode of action of the auxinic herbicide dicamba. PLoS ONE. 2011;6:1-11.

Goggin E.D. et al. 2,4-D resistance in wild radish: reduced herbicide translocation via inhibition of cellular transport. J Exp Bot. 2016;67:3223-35

Green J.M., Owen M.D.K. Herbicide-resistant crops: utilities and limitations for herbicide-resistant weed management. J Agric Food Chem. 2010;59:5819-29.

Grossmann K. The mode of action of auxin herbicides: a new ending to a long, drawn out story. Trends Plant Sci. 2000;5:506-8.

Grossmann K. Auxin herbicides: current status of mechanism and mode of action. Pest Manage Sci. 2010;66:113-20.

Heap I. The international survey of herbicide resistant weeds. [access May 1 ${ }^{\text {st }}, 2016$ ]. Available at: www.weedscience.org.

Kelley K.B., Riechers D.E. Recent developments in auxin biology and new opportunities for auxinic herbicide research. Pest Biochem Physiol. 2007;89:1-11.

Kruger G.R. et al. Control of horseweed (Conyza canadensis) with growth regulator herbicides. Weed Technol. 2010;24:425-9.

Lym R.G. Leafy spurge (Euphorbia esula) control with glyphosate plus 2,4-D. J Range Manage. 2000;53:68-72.

Maciel C.D.G. et al. Misturas em tanque com glyphosate para o controle de trapoeraba, erva-de-touro e capim-carrapicho em soja RR. Rev Ceres. 2011;58:35-42.

Monquero P.A. et al. Glyphosate em mistura com herbicidas alternativos para o manejo de plantas daninhas. Planta Daninha. 2001;19:375-80.

Norsworthy J.K., Grey T.L. Addition of nonionic surfactant to glyphosate plus chlorimuron. Weed Technol. 2004;18:588-93.

Owen L.N. et al. Evaluating rates and application timings of saflufenacil for control of glyphosate-resistant horseweed (Conyza canadensis) prior to planting no-till cotton. Weed Technol. 2011;25:1-5.

Gleason C. et al. Inheritance of resistance to the auxinic herbicide dicamba in Kochia (Kochia scoparia). Weed Sci. 2009;57:43-7.

Procópio S.O. et al. Utilização de chlorimuron-ethyl e imazethapyr na cultura da soja Roundup Ready ${ }^{\circledR}$. Planta Daninha. 2007;25:365-73.

Rodrigues B.N., Almeida F.S. Guia de herbicidas. Londrina: IAPAR, 2011. 697p.

Ronchi C., Silva A.A., Ferreira L.R. Manejo de plantas daninhas em lavouras de café. Viçosa, MG: Universidade Federal de Viçosa, 2001. 94p. 
Santos I.C. et al. Eficiência do 2,4-D aplicado isoladamente e em mistura com glyphosate no controle de trapoeraba. Planta Daninha. 2002;20:299-309.

Soares D.J. Control of glyphosate resistant hairy fleabane (Conyza bonariensis) with dicamba e 2,4-D. Planta Daninha. 2012;30:401-6.

Spaunhorst J.D., Bradley K.W. Influence of dicamba and dicamba plus glyphosate combinations on the control of glyphosateresistant Waterhemp (Amaranthus rudis). Weed Techonol. 2013;27:675-81.

Streibig J.C. Herbicide bioassay. Weed Res. 1988;28:479-84.

Takano H.K. et al. Efeito da adição do 2,4-D ao glyphosate para o controle de espécies de plantas daninhas de difícil controle. Rev Bras Herbic. 2013;12:1-13.

Thompson Jr. L. et al. Action and fate of 2,4-D and dicamba iin Trumpetcreeper. Weed Sci. 1973;21:429-32.

Vink J.P. et al. Glyphosate-resistant giant ragweed (Ambrosia trifida) control in dicamba-tolerant soybean. Weed Tecnhol. 2012;26:422-8. 